RESEARCH ARTICLE

\title{
Designing a Collaborative Peer-to-peer System for Archaeology: The DigVentures Platform
}

\author{
Brendon Wilkins
}

\begin{abstract}
Digital technologies are ubiquitous in archaeology, and have been argued to improve workflows across the archaeological knowledge chain; but to what extent have digital tools materially changed the nature of archaeological scholarship or the role of archaeologists in knowledge production? This paper compares a traditional 'pipeline' with a networked 'platform' model of fieldwork, assessing the impact of technologyenabled participation on archaeology's disciplinary and professional boundaries. In contrast to the collaborative potential of peer-to-peer systems, the current vogue for intra-site digital tools (such as tablet recording, GIS, and 3D technologies) can be seen to augment rather than reinvent pre-digital workflows. This point will be illustrated through an assessment of the UK based collaborative platform, DigVentures, in contrast with recent high-profile initiatives to transition to digital workflows by other established field projects. Evaluated through the lens of Nesta's recent typology of platform organisations in the 'collaborative economy', it will model the underlying dynamics of peer-to-peer interaction by utilising the 'Platform Design Toolkit', considered alongside a worked project example and assessment of digital web analytics of the DigVentures platform. It will finally consider how a peer-to-peer system is experienced by scholars themselves, and the changing role of the archaeologist in a system that shifts the locus of work beyond the physical limits of an organisation, to open up the archaeological process to anyone who chooses to participate.
\end{abstract}

Keywords: Peer-to-peer; crowdfunding; crowdsourcing; platform; digital; collaborative economy

\section{Introduction - problem solvers and solution seekers}

When the science fiction author William Gibson remarked that "the future is already here - it's just not evenly distributed" (Rosenberg 1992), he could well have been describing the archaeology profession. From algorithmic newsfeeds to always-on mobile technology, archaeologists live their non-professional lives in an increasingly networked digital environment. However, contra Galeazzi and Richardson-Rissetto (2018), it is a stretch to think that the internet has impacted archaeological method and practice to quite the same degree. The pervasive use of digital technology may well be entrenched in archaeology, leading some to proclaim "we are all digital archaeologists now" (Morgan and Eve 2012: 523). But in contrast with initiatives from outside the discipline that draw on collaborative models of 'open', 'peer-to-peer', or 'distributed' innovation (Von Hippel 1988; Von Hippel 2005; Chesbrough 2003; Benkler 2004; Benkler 2006), the so called digital turn in archaeology looks very much like a turn inwards, deploying digital tools such as tablet recording, GIS and 3D technologies to augment rather than rein-

University of Leicester and DigVentures, GB

brendon@digventures.com vent pre-digital workflows. Despite the ready availability of potentially transformative technologies that could open up the archaeological knowledge chain to a networked community, the basic job of archaeology continues to be practiced by a bounded project team of specialists working in traditional formation.

How should archaeologists adapt to this ever-shifting digitally networked landscape, and what opportunities or threats await a meaningful engagement? William Gibson's suggestion is that the future is occupied at the margins; that strategies to cope with uncertainty and embrace opportunity are all readily observable in pockets of innovation and early adoption, and as these niche activities become increasingly assimilated into the mainstream, the future becomes the present (Gibson 1990).

This paper is about engagement and experimentation with one of those possible futures: the emerging digital and collaborative economy. Taking cues from other successful social and cultural initiatives at the margin of our discipline, it will introduce the UK-based DigVentures collaborative platform, and assess the implications for archaeology (and archaeologists) of a networked peerto-peer approach to field work. Launched in 2012, DigVentures is a social enterprise with a mission to expand civic engagement with archaeological research by experimenting with alternative business models and 
technology-enabled participation (Wilkins 2013). Ethically positioned as a 'social contract' between archaeologists and as greater range of stakeholders and participants as possible (Wilkins 2012; Neal 2015: 351), the organisation has benefited from the ability to design its systems and digital tools unencumbered by the legacy processes that often govern the organisational activities of a longestablished project, company or institution. The clearest example of this digital reworking of traditional practice is DigVentures' revenue model of crowdfunded and crowdsourced archaeology. This approach that has been implemented on 40 archaeological projects in the UK, Europe and the US, raising approximately $£ 1.2 \mathrm{M}$ for excavation through crowdfunding and matched grant funding, is supported annually by over 1,000 participants. Less discernible but potentially more significant has been the development of a platform approach to archaeological resource sharing, collaborative knowledge production, and crowdsourced labour. This is facilitated by a suite of networked digital tools creating an accessible space for micro-volunteering initiatives and experiences, enabling both tangible and intangible connections between peer producers, peer consumers, stakeholders and partners.

The concept of the commons, and in particular, 'commons-based peer production' (Benkler 2006), has been constructively utilised to frame this modality, "whereby the community (virtual, physical or both) participate in the innovation process and have unlimited access to the tools that are co-developed by the community" (Boyd 2018 xxiv). By shifting the locus of work beyond the traditional physical and organisational limits of a project team, these digital architectures of participation present a significant opportunity to draw on expertise beyond the knowledge boundaries of the professional archaeological community. The epistemic advantages of engaging nonprofessional participants in the knowledge production process has been argued to result in "some of the best research in the social sciences," ensuring that professional biases and concomitant errors are exposed (Wylie 2014: 68). A bounded scientific community of practice may fail to recognise the inherent shortcomings of their basic assumptions and norms of justification, an epistemic limitation that can be mitigated by drawing on a wide range of perspectives from outside the discipline. Characterised as 'participatory action research' and 'community-based participatory-research' across the social sciences (Chevalier and Buckles 2013), and defined more specifically as 'collaborative archaeology' within our discipline (McAnany and Rowe 2015) this approach "is credible... because it is self-consciously situated and brings diverse angles of vision to bear on its central knowledge claims" (Wylie 2014: 68). This demands a "rethinking of traditional views of objectivity that takes social, contextual values to be a resource for improving what we know, rather than inevitably a source of compromising error and distortion" (Wylie 2014: 69).

Such an approach seems wholly aligned with the profession's determination to realise a wider public benefit (Scanlon et al. 2011), however, far from embracing the possibility of meritorious contributions from the crowd, some archaeologists have raised concerns regarding the potential disintermediation of long-established gatekeeper organisations (Perry 2015; Perry and Beale 2015), reanimating debates concerning the contemporary role of archaeologists in a digitally mediated landscape (Brophy 2018; González-Ruibal et al. 2018; González-Ruibal 2018; Perry 2019; and aspects of Nativ 2018 are also relevant here). Archaeological expertise is hard won, and current concerns regarding the profession's contemporary status should be seen as more than luddite opposition to change for change's sake. Disciplinary boundaries serve to distinguish archaeologists from lay people, with an array of sub-disciplinary boundaries ordering professionals into period and material specialisms. This contrasts with peerto-peer networks, where seemingly little is known about which individuals and communities participate, how they participate or their motivation for doing so. In an era of 'Post Truth' (Oxford Dictionary 2016) and 'Filter Bubbles' (Pariser 2011), it could be argued that knowledge boundaries establish trust and legitimacy, guarding society against the potential misuse of the past from "an aggressive miasma of atavistic speculation" (Trigger 2006: 547). How could such checks and balances, a notion characterised in contemporary discourse as 'Old Power' (Timms and Heimans 2018), be applied to a resolutely 'New Power' peer-to-peer system that furnishes anyone who chooses to participate with the tools to join in?

This dilemma is well illustrated by a recent study of the effects of NASA's experimentation with 'open innovation', a process that was revealed through an in-depth threeyear longitudinal field study by a researcher embedded with NASA's scientific community (Lifshitz-Assaf 2017). Under financial pressure from Congress, in 2010 the organisation published fourteen strategic challenges on open innovation platforms (Innocentive, Topcoder and Yet2). Overwhelmed by 'the 'spectacular results' of the open innovation experiment" (Lifshitz-Assaf 2017: 757), NASA's management sought to integrate open innovation into the day-to-day workflow of the organisation. But enthusiasm for this initiative was far from unanimous with NASA's scientific community, leading to "rising tensions, emotions and fragmentation" (Lifshitz-Assaf 2017: 758). Studies of open innovation have hitherto tended to focus on the role of the peer-to-peer platform itself or the character of contributing communities (Chesbrough, Vanhaverbeke, and West 2014; Benner and Tushman 2015). Lifshitz-Assaf expanded her analysis to account for the role of identity, investigating how professionals may adopt or reject change and innovation depending on whether this contradicts or supports their professional sense of self and purpose. Through structured interviews and close observation, her conclusion was that "open innovation challenged not only the knowledge-work boundaries of R\&D professionals but also, to a great extent, their professional identity" (Lifshitz-Assaf 2017: 767).

From this insight, she identified two main groups, which she called 'problem solvers', who self-identified with a bounded, scientific method adhering to notions of professional expertise and peer review, and 'solution seekers', open to collaboration and dismantling professional 
boundaries. These divisions could not be explained by demographics or socioeconomics (both groups were equally varied), and given the scientific mission of the organisation, nor was this a reaction to technological change or the validity of the experiment's results.

Returning to the theme of this special issue, we may question whether the on-going debate on the theoretical and philosophical aspects of digital scholarship originates from within a 'problem solver' or 'solution seeker' mindset. Does this schema reflect the differences between those who advocate for a sub-disciplinary bounded digital scholar positioned "at the heart of the larger discipline" (Perry and Taylor 2018: 11), in contrast with those who claim for a post-digital, normative stance summed up by Costopoulos (2016) who argues "I want to stop talking about digital archaeology. I want to continue doing archaeology digitally."

Huvila and Huggett (2018), in their positioning paper on digital scholarship, articulate "the need for at least a relative consensus" on how archaeological work is currently organised as a first step to addressing this debate. In line with Lifshitz-Assaf's call "to zoom out of the existing 'How' we do our work, to pause, reflect and refocus on the bigger "Why'" (Lifshitz-Assaf 2018) these authors similarly advocate for a zooming in and zooming out on archaeological practice and knowledge work, seeking to go beyond "the rules, formal descriptions, etc. and hence what essentially constitutes canonical practice, but also... what actually takes place: the day-to-day reality of the practice" (Huvila and Huggett 2018). Continuing in this vein, the following discussion will initially 'zoom out' to consider archaeological work in the UK in terms of its dominant business and operational models (understood here to be a blueprint describing how an organisation creates, delivers and captures value, in economic, social, cultural or other contexts) considering how this poses structural challenges to opening up the archaeological knowledge chain to public participation.

This will be followed by a 'zooming in' on contemporary digital practice to contrast a traditional 'pipeline' with a networked 'platform' model of field work. Whereas a born digital approach may be afforded the advantage of designing collaborative networked digital tools from the ground up, long-established organisations transitioning their legacy processes to a digital methodology can be seen to augment rather than reinvent their pre-digital workflows, consolidating disciplinary boundaries and maintaining traditional working practices in a manner unlikely to confront the profession's structural challenges.

\section{From Atoms to Bits - digital archaeology's social context}

Though archaeology may be characterised as a research endeavour, it is predominantly practiced as a service sector, presenting an overwhelming structural challenge to the widespread adoption of technology-enabled civic participation in the knowledge production process. The profession predominantly comprises a state-backed 'conservation sector' designed to protect and maintain natural and built heritage, with a largely private 'mitigation sector' constituted to respond to the former's demands (Bradley 2006; Carver 2010; Carver 2011). Of the 6,812 paid archaeologists working in the UK in 2017-8, it is estimated that $72 \%$ worked for organisations that provided commercial field investigation and research services (the mitigation sector), and 6\% for organisations that provided historic environment advice (the conservation sector), with the remainder employed outside the development-led market dynamic within museums, universities and civil organisations (Aitcheson 2019: 20).

The current dominant form of archaeological work emerged as a result of the increased demands for archaeologists following post-war urban reconstruction. The Rescue Revolution, and the later growth of Cultural Resource Management through the 1970's and 1980's depended on standardisation and repeatable procedures (Jones 1984), a move that was further consolidated in the 1990's in Britain with the issue of PPG16/15 and MAP 2 (Wainwright 2000). The net result is that $90 \%$ of all archaeological work practised in the UK since 1990 has taken place within the commercial mitigation sector, mostly as a precondition to receiving planning permission as part of the development process (Fulford 2011: 33). From relatively modest pre-1990 state funded levels of $£ 14$.3m per annum, the total revenue generated by UK commercial archaeology in 2017-18 was approximately £239m, resulting in over 75,000 planning related archaeological investigations (Trow 2016: 57; Aitcheson 2019: 28).

From inauspicious beginnings to significant contributor to the wider economy, Watson (2019: 3) argues that commercial archaeology's plucky back story is often presented as a heroic

\section{"'foundation myth'... with little critical awareness of the myriad difficulties (e.g. the fragmented, com- petitive nature of the contracting sector) that have perpetuated and, arguably, held back the develop- ment of a mature and respected occupation."}

The boom and bust cycles of the construction industry have enabled a fragmented and competitive business model to take root "within the vacuum created by a lack of alternative models" (Watson 2019: 3). Operationally this model can be described as a pipeline workflow: designing a product or service and following a step-bystep system to deliver the product or service in a linear value chain with producers at one end and consumers at the other (Figure 1). The ultimate goal of these predominantly client-funded investigations is to understand a site's formation processes, reporting results in 'grey literature'. When research does occur - understood here to be a synthesis of archaeological results to understand the historical processes that gave rise to those formation processes - this is usually conducted by a much smaller academic sector and paid for by research grants (Bradley 2006; and see Fulford and Holbrook 2015 for an exceptional example of where synthesis has been achieved in spite of market logics).

The pipeline model of archaeological knowledge creation is exemplified by Barry Cunliffe's influential 'Levels of 


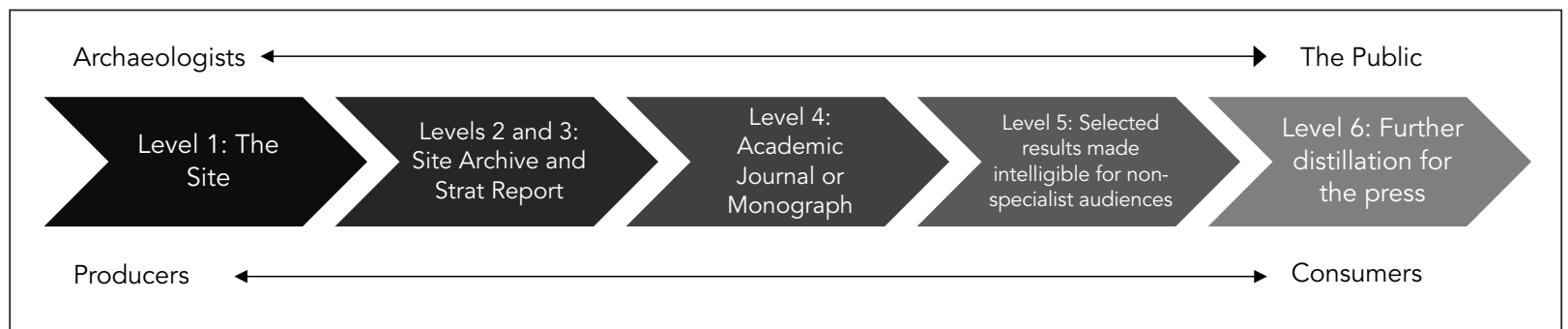

Figure 1: Cunliffe's Levels of Publication (1983) illustrated as a unidirectional pipeline articulating the relationship between producers and consumers. DigVentures.

Publication' concept (Cunliffe 1983). Based on a series of consecutive steps, his model was designed to ensure that archaeological knowledge could be produced for a range of specialist and non-specialist consumers. Level 1, he argued, was the site itself, with its unrealised information preserved in situ; this was followed by Levels $2 \& 3$ represented by the archaeological producers' easily accessible site archive and stratigraphic report. An academic journal or monograph publication would follow with Level 4, with selected results made intelligible for non-specialist consumers at Level 5 (the public) and 6 (the media). This closed cycle has enabled archaeology in the UK to grow into a commercial service industry embedded with environmental risk management, but there are significant structural issues with a model which rests on the assumption that the material remains of the past are a physical 'asset' framed as a 'non-renewable resource'.

This approach enables a workflow where interpretive decisions can be delayed to a later phase of the project because the material uncovered by the excavation and the record produced by the individual excavator is seen as impartial and atheoretical. But this is far from ideal, and methodologies that box, bag and label the material remains into easily managed categories for interpretation at a later date have been argued to vastly reduce our capacity to discover what the existential poet Donald Rumsfeld would call 'unknown unknowns' (Wilkins 2009). The consequence of this for Berggren and Hodder (2003) is the reduced intellectual status of field workers (see also Everill 2009):

"The old theoretical debate about the separation between data and interpretation in archaeology partly has a social basis. It is not an abstract philosophical discussion. It is about who is empowered to interpret. And on the whole the answer has been 'not the excavator'" (Berggren and Hodder 2003: 425).

Martin Carver counters that "it is hard to recognise the social basis for this report, which appears to emanate from the planet Zog" (2011: 74). Far from restating an older antiquarian-labourer class system, Carver (2011: 74) reminds us that

"in archaeology, as in the rest of the world of work, you are paid to do what is wanted by the person with the money, not to do what you would rather be doing... so there are two parallel parts to our profession: people paid to produce new research, mainly in universities, and people paid to manage research resources, mainly in government, underpinned by a large commercial sector."

Given that $52 \%$ of people working in the commercial mitigation sector in the UK are employed by "not-fordistributable profit organisations (registered charities, constituent parts of local planning authorities, constituent parts of universities)" with a social and educational mission (Aitcheson 2019: 11; Dore 2019: 24), it is no small irony that the sector has gravitated towards a business model that challenges its basic professional precepts (see Scanlon et al. 2011; Nixon 2017; Wills 2018). It is not unusual for charitable bodies to establish commercial trading arms in order to fund their wider mission, however, in 2017-18 the "community, public archaeology and educational work" undertaken by archaeological organisations in the UK was calculated at just $2.1 \%$ of those organisations' average annual turnovers (Aitcheson 2019: 29). This seems like a vanishingly small percentage, but by failing to capture the 'non-market' transactions that would underpin a thriving civic sector, perhaps this exclusively market orientated analysis is misleading. Following Carver's reasoning above, what does the growth of the commercial mitigation sector mean for people not paid to do archaeology, but who choose through voluntary endeavours to do it anyway?

With a long tradition of voluntary participation in British archaeology reaching back into the $19^{\text {th }}$ and early $20^{\text {th }}$ century, a survey by the Council for British Archaeology of local archaeology group members has estimated that 215,000 people self-identify as regularly engaged with archaeology (Thomas 2010: 23); these numbers suggest a thriving voluntary scene which could be a solid foundation for the development of technologyenabled civic participation. However, closer scrutiny of voluntary archaeology societies suggests that membership is aging and in decline; the majority of members surveyed for the CBA report were over 60 , a pattern also observed when the membership was surveyed once again in 2018 (Figure 2), which concluded that the membership had contracted, and those remaining were now eight years older (Frearson 2018: 13). This aging demographic is also supported by a regional study of voluntary groups in the East of England where just 9\% of members were aged between $18-40$ years old, and only $17 \%$ were in full time 


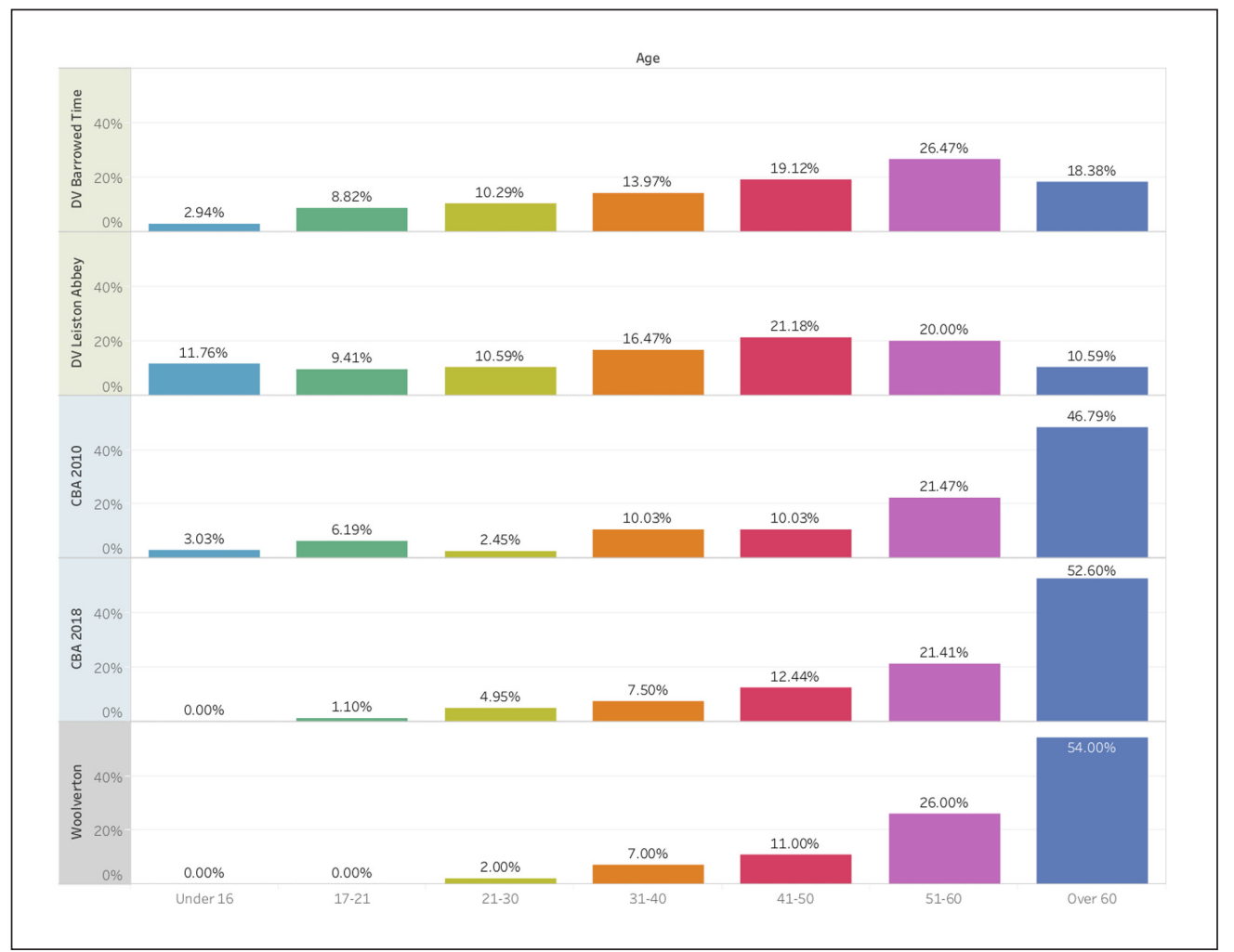

Figure 2: Comparison of age profiles of Council for British Archaeology membership undertaken by Thomas (2010) and Frearson (2018), a regional survey of community groups in the East of England (Woolverton), contrasted with a typical age profile from a four-year DigVentures project (Leiston Abbey) and the Barrowed Time project. DigVentures.

employment (Woolverton 2016). No national socioeconomic audit has been undertaken of archaeology society membership, but anecdotally, clubs and societies typically comprise a largely passive group of overwhelmingly white, middle class, and retired members, corralled by a handful of active committee members, the "preserve of the retired, of the established, of the pedantic..." (Manley 1999: 111). Far from creating space for civic participation with archaeology, the dramatic uplift in resourcing for developmentled work has exacerbated this contraction, with $74.6 \%$ of volunteer projects operating outside the major sources of funding for archaeology and a large proportion failing to uphold the basic ethical requirement of sharing or publishing data (Hedge and Nash 2016: 88).

'Zooming in' now on mainstream digital practice, and rather than experiment with 'open', 'peer-to-peer', or 'distributed' models that could address archaeology's systemic challenges (Von Hippel 1988; Von Hippel 2005; Chesbrough 2003; Benkler 2006), innovation has taken a much narrower focus on digitising rather than reimagining traditional workflows. In consequence many of the same structural concerns raised with archaeology's dominant business model persist, though restated in a digital context. Perry and Taylor (2008: 11) note that "the technical capacities of these [digital] tools still tend to eclipse meaningful critique of their implications," lamenting the "lack of a larger critical disciplinary framework to guide digital practice." Alongside a concern that "digital applications generally make it near-impossible to recognise or interrogate power dynamics at play, leaving us blind to (and liable to reproduce) structural inequalities" (2018: 16), other, 'pre-digital' arguments are also transposed: "digital archaeology might in some cases be mistaken for a form of 'neo-processualism', focused on specifications, accuracy, and precision as means to generate increasingly 'real' archaeological models" (2018: 14).

Layered upon the archaeology profession's existing structural tensions, the widespread digitisation of traditional workflows resonates with ongoing anxieties regarding the future of archaeological work and skills. These concerns are based on the critique that the rise of industrial capitalism leads to either the deskilling of workers following the introduction of machinery and the resulting redundancy of hard-learned craft skills (Braverman 1974), or the upskilling of workers who will need new educational qualifications to either operate or design that machinery (Bell 1973).

Following other pioneering experiments with digital recording systems at sites in the UK such as West Heslerton (Powlesland and May 2010) and the Silchester Town Life Project (Clarke et al. 2003), the 'Braverman/Bell' debate echoes through recent reports of the development of digital recording systems using mobile devices in academic fieldwork (Walcek Averett et al. 2016). Enthusiastic adoption of digital recording at Pompeii noted that moving to a digital platform increased productivity by greater than $300 \%$ with around one third of the typical staff (Poehler and Ellis 2012: 2). Acknowledging the increased accuracy of digital recording methods enabling the excavator to efficiently collect ever more data, Caraher urges caution, advocating for a "slow archaeology... as a meticulous, integrated craft that resists the fragmented 
and mechanised process of the assembly line" (Caraher 2016: 436). Roosevelt et al. argue the upskilling hypothesis: "increasing efficiency... [enabling] fuller engagement with the material record in the field while simultaneously increasing the technical literacy of project participants" (Roosevelt et al. 2015: 339). This position has also been adopted in a series of reports that have emerged recently from the Çatalhöyük Research Project (CCRP) (Berggren et al. 2015; Taylor et al. 2018; Lukas et al. 2018), claiming for the 'democratisation' potential of tablet computers to address archaeology's structural challenges.

The programmatic aims of 'reflexive archaeology' determine that excavators should be conscious of why they do what they do (reflexivity), enabling multiple interpretations of archaeological evidence (multivocality), and conscious of the situated nature of knowledge production (relationality). Through these means "reflexive archaeology... provides systematic opportunities for field archaeologists to engage in narrative construction and to provide critique of those narratives in relation to data and social context" (Berggren and Hodder 2003: 426). The introduction of web-viewable relational databases and tablet computers connected to a local network has been called a 'living archive' enabling

"deep integration of knowledge on site... it effectively brings that part of the archive which is generally conceived of as being accessible 'offsite' (or perhaps even only accessible post-excavation) 'on-site', transforming the archive from a static reference knowledge-base to a dynamic interpretative tool in its own right" (Taylor et al. 2018: Section 12).

This process is seen as enabling "many aspects of data manipulation, validation and interpretation, which are ordinarily reserved for certain 'privileged' individuals during the post-excavation process, into the field at the trowel's edge" (Berggren et al. 2015: 446). Pictured schematically, however, it is difficult to recognise how ÇRP's 'hierarchy of knowledge production' fundamentally deviates from Cunliffe's levels of publication concept (Berggren et al. 2015: 445, Figure 7). Commensurate with level 1 on Cunliffe's pipeline is what ÇRP would define as “'The Site' itself, which can be seen (perhaps fairly conventionally) as a primary resource for the generation of interpretations and knowledge for those who interact with it." Cunliffe's level 2 and 3 correspond with ÇRP's 'Archaeologist' tier, "an agent for observing, recording and interpreting the site. In this sense 'archaeologist' refers to any team member, of any specialism, that has some input into the generation of data and its subsequent interpretation" (Taylor et al. 2018: Section 9). Levels 4, 5 and 6 map on to ÇRP's top level -

"the various strands of output and dissemination of data and its interpretation, most commonly in the form of the archive and various tiers of publication, these being ultimately the physical manifestation of the team's "Generation of Knowledge'" (Taylor et al. 2018: Section 9).
Despite these parallels, the digitisation of traditional practice is still argued to materially challenge the knowledge production process because digital tools are "ontologically generative... emphasising the breadth of what can be called the archaeological" (Shanks and Witmore 2012), "hence there would be no archaeologists without archaeological stratum or the tools of their trade, or vice versa" (Huvila and Huggett 2018: 89). This mode of analysis has also been applied by CCRP, conceiving of archaeological practice as a bounded social network of practitioners deconstructing a site in the field in order to reconstitute the site into digital media (Taylor et al. 2018: Section 3). However, just as the mediating practice of field photography has come to determine the hygienic practices of excavation (such as the notion of cleaning up for a photo), it is difficult to see how scholarship will be materially transformed by digitising that practice (or other intra-site digital replacements for traditional tools). By focussing on the mobile devices themselves - no matter how sophisticated "the tablets, and the suite of associated digital technologies that they allow in the field" (Berggren 2015: 446), this and other recent high profile initiatives to transition to a digital workflow by established field teams could be overlooking the revolutionary potential of these networked devices. This does not discount that tablet computers could transform practice, but without a similar shift in operational and business model, adoption can be seen to be the equivalent of putting alloy wheels and go-faster stripes on a horse and cart.

\section{Archaeology as a peer-to-peer platform}

There is a persistent perception that archaeology can be organized according to either socialist or capitalist principles: projects can be delivered either as a public service paid through taxation or procured through a private market of service suppliers (Kristiansen 2009; Willems and van den Dries 2007). This assumption of a clear boundary between public and private is contradicted by David Graber's (2015: 9) insight that
"any market reform, any government initiative intended to reduce red tape and promote market forces will have the ultimate effect of increasing the total number of regulations, the total amount of paperwork, and the total number of bureaucrats the government employs."

With equivalent key performance indicators, audit trails, internal markets and management hierarchies, Graber's 'Iron Law of Liberalism' recognises that "public and private bureaucracies have become so increasingly entangled that it's often very difficult to tell them apart" (Graber 2018: 17).

In their 2011 book, 'what's yours is mine', Botsman and Rogers sought to move beyond the binary opposition of either socialist or capitalist formations, observing the proliferation of new kinds of marketplaces, businesses and communities emerging to help people to access the things they need in new and different ways, while also making the things they owned available to others. Calling this phenomenon 'collaborative consumption', they defined it 
as "the reinvention of traditional market behaviours, such as bartering, renting, trading and exchanging, through technology, enabling them to take place on a scale and in ways never possible before" (Botsman and Rogers 2011).

The underlying business model of these collaborative, peer-to-peer platforms is far from new, drawing on a similar two-sided market place that enabled the formation of the London Stock Exchange in 1801; what is different is the affordances provided by digital peer-to-peer platforms, which can be characterised as an ecosystem enabling different types of users to connect and conduct interactions with one another, facilitating the exchange of goods, services or social currency. Though focussed initially on shifting consumer habits, Botsman and Rodger's definition was expanded by Nesta (Stokes et al. 2014) into a broader conception of 'collaborative economy' to account for new forms of production summarised into a four-pillared typology. From collaborative resourcing models (like Airbnb) and collaborative finance (like Kickstarter), to collaborative production (like Wikipedia) and collaborative learning (MOOCs like Future Learn), these organisations draw on 'network effects' (Shapiro and Varian 1999: 184), making use of idle assets and creating new marketplaces, and in so doing challenge traditional ways of doing business, rules, and regulations.

In contrast to pipeline models where control of the 'supply-side' of the production process confers competitive advantage, network effects bequeath digital platforms with the capacity to build 'demand-side' communities of interest. And just as supply-side economies of scale can lead to industrial monopolies, network effects have also led in some instances to the monopolistic dominance of GAFA-type platforms (Google, Apple, Facebook and Amazon) able to extract data and wealth from the network. But this is not an inevitable consequence of a platform model, and there are numerous other organisations that have taken this approach to address social and cultural challenges, with any accruing network benefits socialised amongst the platform's users (Mason 2019; Zuboff 2019). Countering the Silicon Valley trend of venture-funded enterprises seeking to 'move fast and break things', there are a multitude of ventures conversely seeking to 'move fast and fix things', experimenting with platform cooperatives, alternative currencies and distributed autonomous organisations (exemplified by the differences between Airbnb and Fairbnb) (Fairbnb Manifesto 2019; Pick 2019: 60). Closely aligned with these social impact initiatives, the DigVentures platform was developed to apply network effects to archaeological workflows, addressing the central design challenge of how to improve research outputs whilst simultaneously creating space for civic participation.

Rather than focus on one of Nesta's collaborative economy pillars with a generalised offer that services all types of projects in the arts and the sciences, DigVentures have concentrated on a single theme, archaeology, to build and service a community around a common interest (Westcott Wilkins 2015). Beginning with the archaeological resource itself, the platform links up owners or custodians of heritage assets with a networked community who want to learn, understand and enjoy those assets (collaborative resources, Figures $\mathbf{3}$ and $\mathbf{4}$ ). This is underpinned by

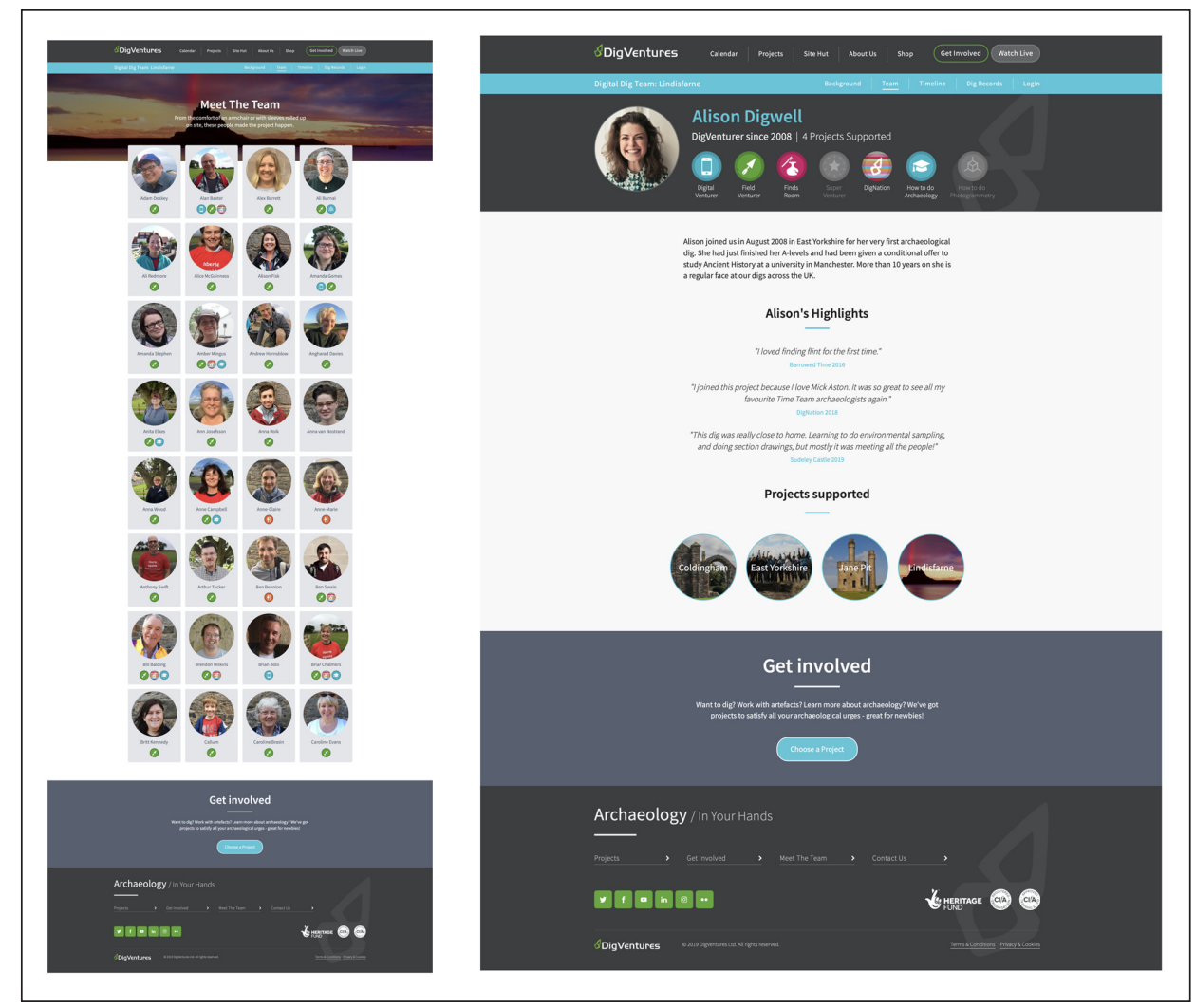

Figure 3: Group and individual profile pages for the DigVentures platform, displaying badges of achievement and projects completed for individual participants. DigVentures. 


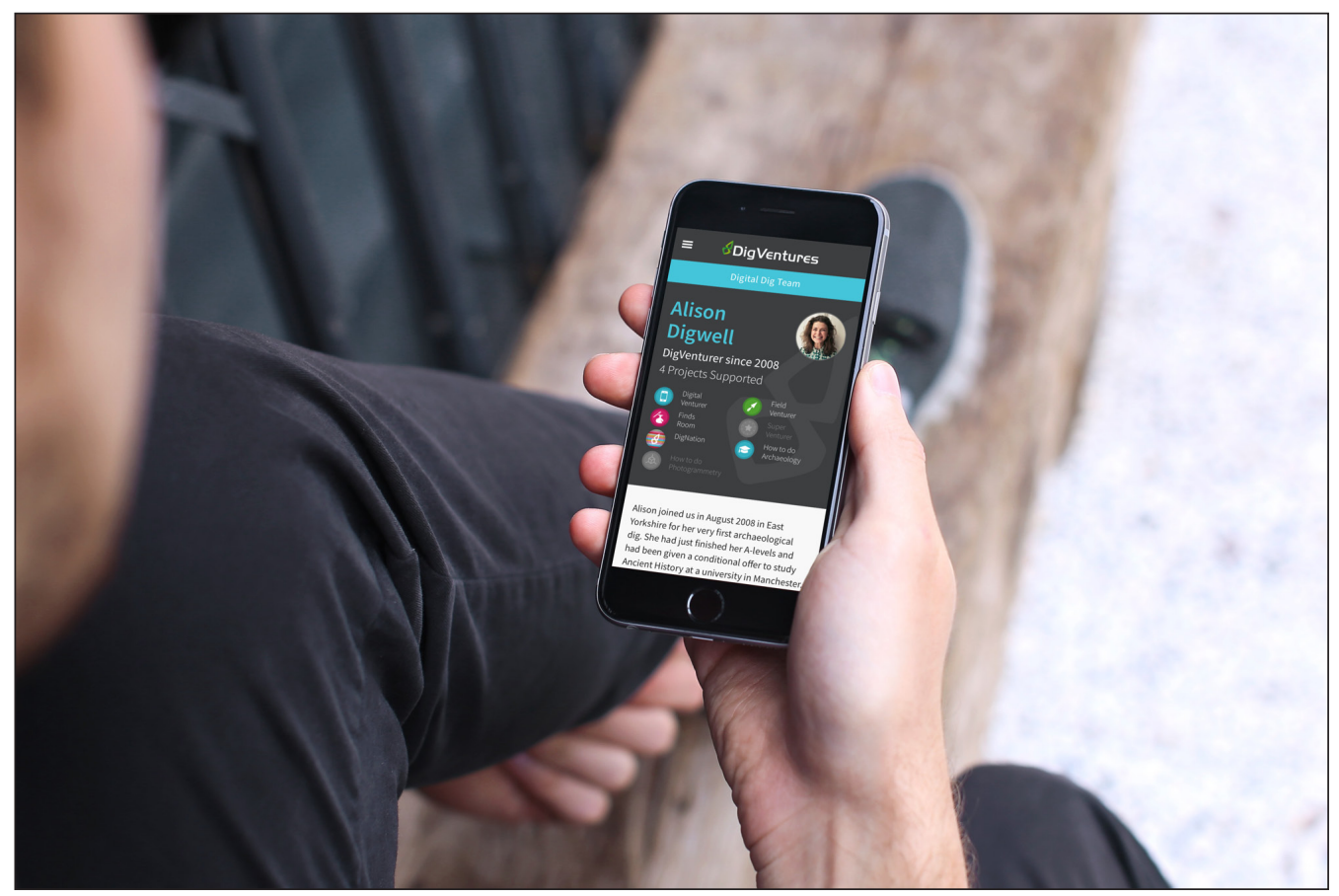

Figure 4: A community management system for archaeology - individual profile pages and badges viewable on mobile devices. DigVentures.

a collaborative finance dimension to the platform, generating income and non-financial contributions from a networked community through crowdfunding and crowdsourcing (collaborative finance, Figure 5). This is supported by a bespoke digital recording system enabling project participants to collaboratively produce text/photos/video and 3D models directly from the trenches using their phones or tablets, harnessing comments and contributions from the crowd (collaborative production, Figure 6). The development of a MOOC platform, or learning management system, has built on this, deepening the audience's engagement with the data through collaborative learning, and extending field skills training to a digital audience (collaborative learning, Figure 7).

The Nesta typology has been of benefit in framing the diversity of activities in the collaborative economy and positioning the DigVentures platform, but appreciating the underlying dynamics of peer-to-peer interaction will require a different analytical tool (Figure 8). The Platform Design Toolkit was developed to assist in modelling emerging, multisided platforms to help shape strategies that could respond to and facilitate existing ecosystems of users to create and exchange value (Cicero 2018). A platform strategy responds to an existing collaborative economy ecosystem by distilling an essential value proposition that seeks to improve and facilitate connections between 'entities' to scale its potential (Figure 8, column c). These entities (Figure 8, column a and d), or actors, can be characterised as platform shapers (owners, ultimately responsible for the strategy); stakeholders (established bodies such as municipal or professional institutes with a vested interest in supporting or regulating the platform); peer producers (individuals or organisations interested in providing value on the supply side of the ecosystem/marketplace); peer consumers (users interested in consuming, utilizing, accessing the value that is created through and on the platform); and partners (professional entities seeking to create additional professional value and to collaborate with platform owners).

Transposed through the Platform Design Toolkit, the DigVentures model can be conceived as a system enabling both tangible and intangible connections between entities, illustrating the channels and contexts through which they exchange value, and the services through which individuals can learn and evolve their participatory role through the platform. The toolkit illustrates how these entities create value through two specific 'engines' - a transaction engine (facilitating interactions between value producers and consumers, Figure 8, column d) and a learning engine (support services that enable platform participants to learn, improve and evolve their capacity to take advantage of the platform, column b). In the attached example, DigVentures is contrasted with a platform many readers will have direct experience of - Airbnb. In the case of the Airbnb platform, peer producers own space, peer consumers seek short term rental of this space, and stakeholders (such as municipal authorities) seek to control the potential impact of short-term rentals on available housing stock. The Airbnb platform facilitates tangible connections (such as booking and taking payment for a room) and intangible connections (such as leaving a review or hosting an experience). The essential value proposition enables peer consumers to afford unique travel experiences, peer producers to supplement their income whilst sharing their culture, and partners/stakeholders to benefit through the platform's collective ownership and democratic governance.

Mapping the entities that interact through the DigVentures platform reveals the 'platform shapers' role to be an in-house team of professional archaeologists, 


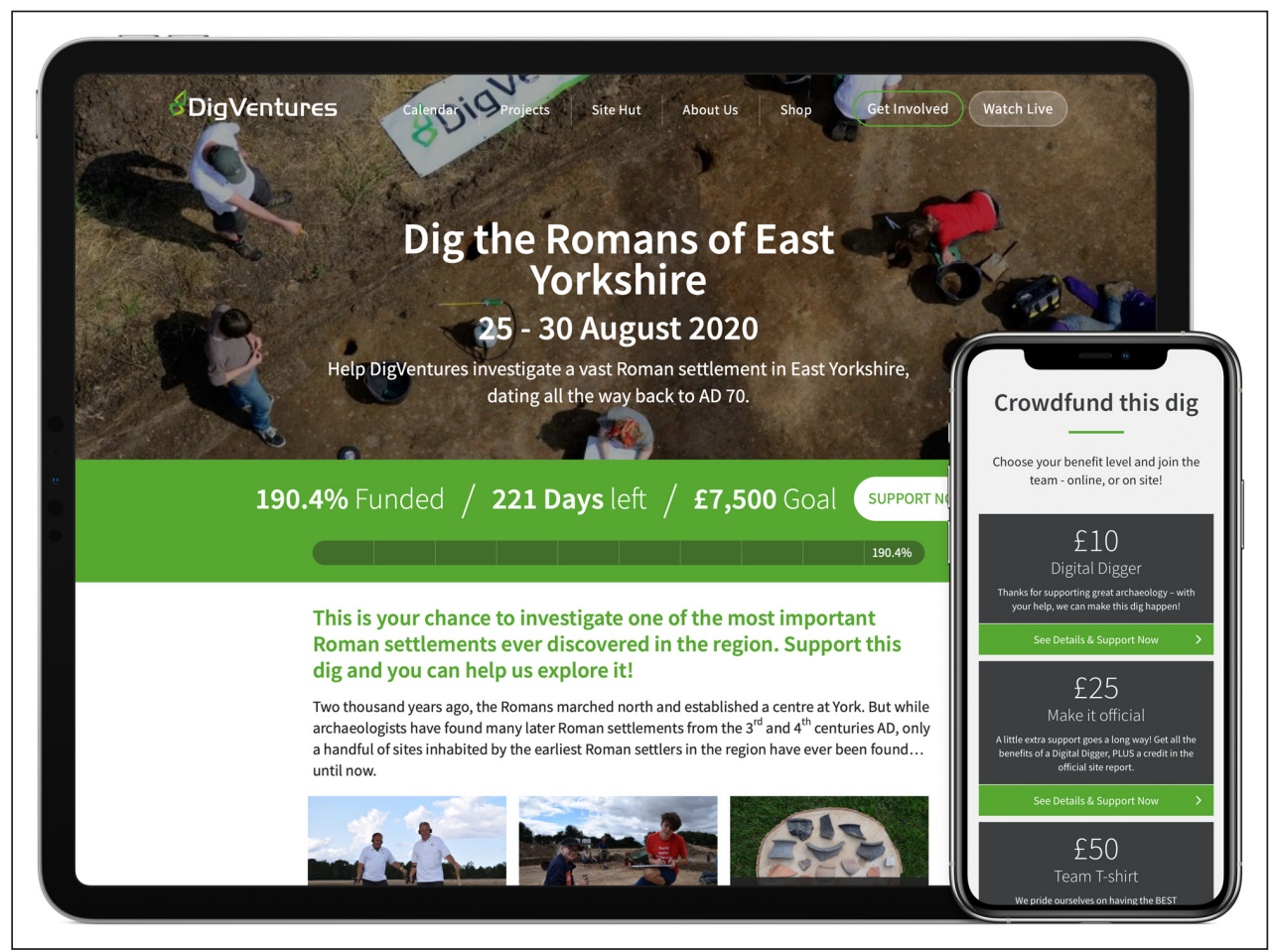

Figure 5: Project crowdfunding and crowdsourcing pages, accepting income and non-financial contributions from a networked community. DigVentures.

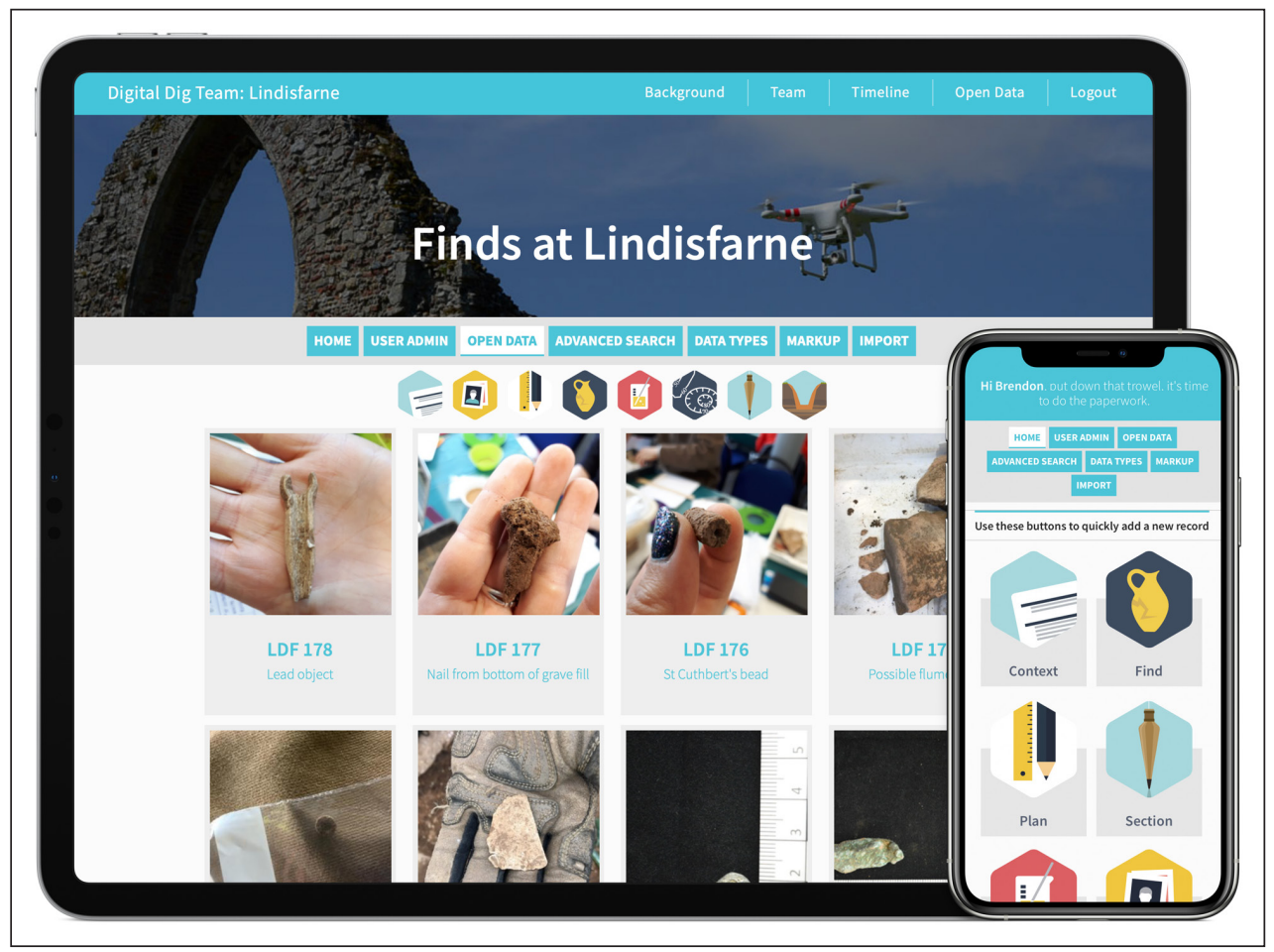

Figure 6: Digital Dig Team recording system, enabling project participants to collaboratively produce text/photos/video and 3D models directly from the trenches using their phones or tablets. DigVentures.

including a digital media team (videographer, writer, photographer and editor). Projects are designed or shaped by the in-house team in partnership with a diverse range of heritage organisations (such as museums, local societies and councils), creating an accessible space for micro-volunteering initiatives and experiences. Partners physically own archaeological dig sites, peer producers want to join digs on these sites, peer consumers enjoy visiting or viewing these digs physically or on line, and stakeholders (such as the Chartered Institute for Archaeologists, Historic England or Local Councils) seek to monitor the quality of these digs through permitting or professional accreditation. The DigVentures platform facilitates tangible connections between peer producers and consumers (such as 


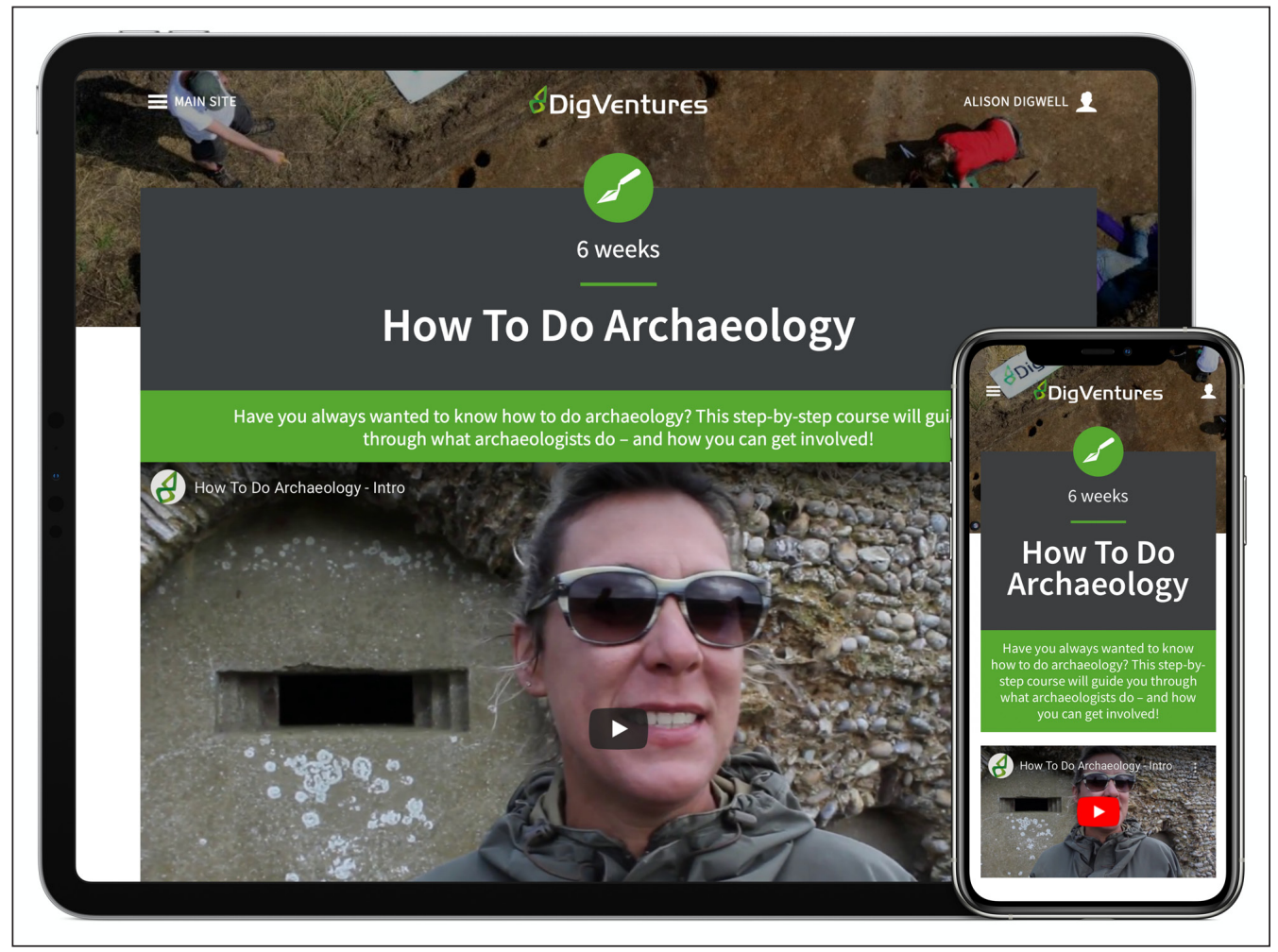

Figure 7: The MOOC platform, deepening the participant's engagement with the data through collaborative learning, and extending field skills training to a digital audience. DigVentures.

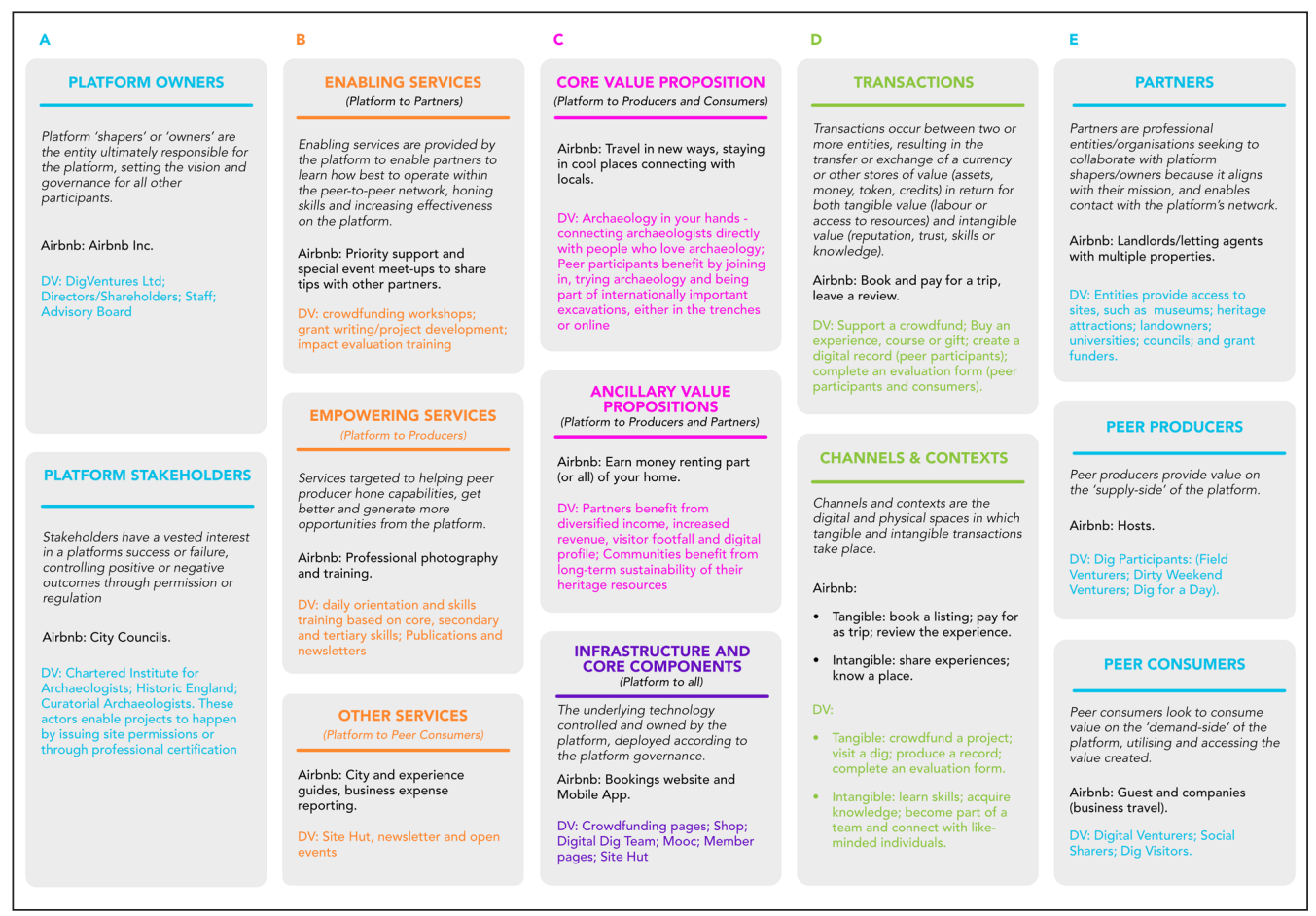

Figure 8: The Platform Design Toolkit (after Cicero 2018) a design canvas used for modelling the different entities (peer consumer, producer, partner and stakeholders) and the channels/contexts through which they exchange value, and the services through which they can learn and evolve their participatory role through the platform. DigVentures.

crowdfunding a project, visiting a dig and completing an evaluation form, or completing a dig record) and intangible connections (such as acquiring skills and knowledge, becoming part of a team and connecting with like-minded individuals). The value proposition differs between entities, with project partners benefiting from diversified income, increased revenue, visitor footfall, and digital profile. Peer participants (producers and consumers) receive heritage skills training and experience as part of important field research projects, and local communities (represented by 
stakeholder entities) benefit from the long-term sustainability of their heritage resources.

The latent assumption contained within Cunliffe's levels of publication concept, and similarly underlying theoretical public archaeology models (see Matsuda 2016), is that archaeology is undertaken 'within' organisations, who then relate to 'the public', resulting in an us/them, top/down knowledge production pipeline. In contrast to the pipeline approach, a platform model can be characterised as an ecosystem, enabling different types of users to connect and conduct interactions with one another, thereby enabling value creation for all entities. Level 5 and 6 'consumption' is not positioned at the end the archaeological workflow, but manifest before, during and after the excavation, continuously funnelling the user into a deeper engagement with the research process. And by the same token, level 2, 3 and 4 'production' is driven through the peer-to-peer engagement of the community, culminating in the research outputs that would be typically expected from a scientific excavation. The underlying technology of the platform includes a publishing hub, information pages encompassing project background and educational resources, e-commerce crowdfunding payment system, and a read/write recoding system enabling project participants to collaboratively produce archaeological data. Taken together as a 'digital stack', this could be described as a 'Community Management System' for archaeology projects - standing in relation to archaeological workflows as Content Management Systems like WordPress stand in relation to web publishing (Westcott Wilkins 2015).

\section{Scaling civic participation - a worked example} Alongside an assessment of project outputs and web analytics, user journeys through the DigVentures platform can be illustrated with a specific project, the 'Barrowed Time' excavation, articulating how a model of collaborative resourcing, finance, labour and learning differs from a traditional pipeline approach. The collaborative resourcing dimensions of the 'Barrowed Time' project (Wilkins et al. 2018) represented the first major excavation of an Early Bronze Age funerary monument in north Lancashire since 1982 (Olivier 1987). The platform linked project partners (the landowner, Durham University and Lancaster City Council) with a network of peer producers and consumers (dig participants and visitors to the project exhibition), managed by an in-house team of ten professional archaeologists from DigVentures. Work was structured as a community-based research project, with fieldwork designed to help contextualise the unexpected discovery of a Late Bronze Age tanged chisel and knife blade by a local metal detectorist on private farmland (Figure 9). Fieldwork was undertaken between the 4th to 17th of July 2016 and between the 11th and 24th of September 2017, revealing several pits dating to the early part of the Middle Neolithic Period, and two Early Bronze Age cremation burials within a Food Vessel Urn and Collared Urn enclosed by a ring cairn on the summit of a hill. This sequence now represents the most intensively radiocarbon dated site of the period in Lancashire and Cumbria (where the lack of scientific dating is frequently lamented) as well as the first use of Strontium isotope analysis on prehistoric cremated human bone in northern Britain (Wilkins et al. 2018).

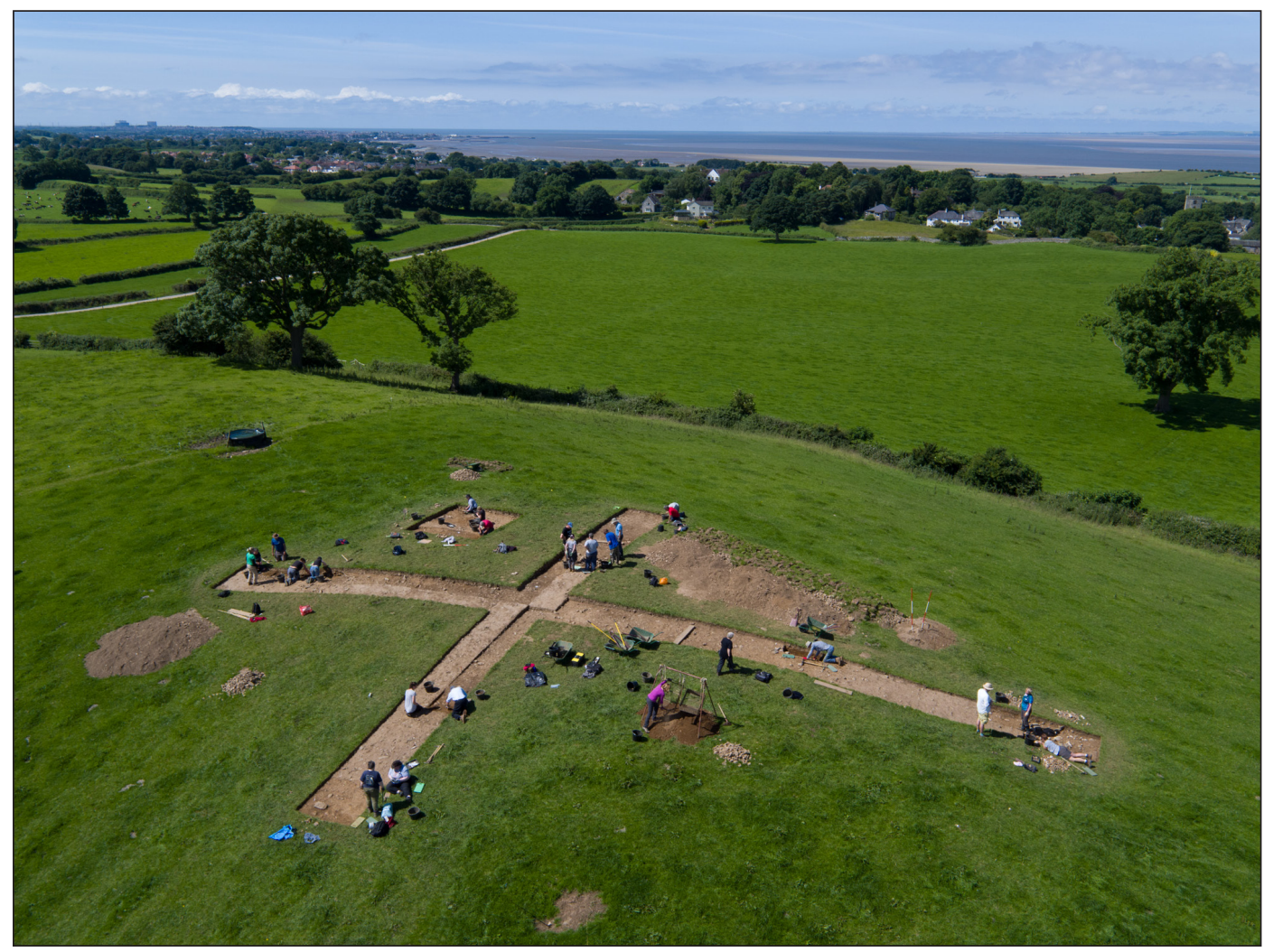

Figure 9: Aerial view of the 'barrowed time' community excavation, looking south-west over Morecambe Bay. DigVentures. 
The site's immediate communities (North Lancaster, Morecambe and Heysham) fall within the $25 \%$ most deprived areas in England, with much lower levels of educational achievement than the national average (Lancaster City Council 2019). A key aim of the project was therefore to engage a far greater demographic than would typically participate in community archaeology, stimulating surrounding communities to become more involved with and enthused about the stewardship of their local heritage. Raising the profile of the site was a particular challenge for the project, given the inaccessible rural location and potential threat of looting. Following the dynamics of the platform design toolkit articulated above, the strategy to address this encompassed delivering structured field school training to peer producers, with peer consumers benefiting from a pop-up exhibition hosted in a disused shop on Morecambe promenade (2016) and in a Lancaster City Council building (2017) supported by schools visits and an online virtual museum (Figure 10). An evaluation survey was completed for both peer consumers (visitors to the project exhibition and digital participants) and peer producers (dig participants) recording their age, gender and professional background as well as socioeconomic categories derived from the Office for National Statistics. This was coordinated through a welcome desk for exhibition visitors (with 166 responses, or $11.5 \%$ of all exhibition visitors) and through a pre- and post-dig interview with 124 dig and online participants (or 60\% of total participants, conducted by email and in person).

A collaborative finance budget of $£ 149,043$ was raised through matched crowd and grant revenue, with $72 \%$ of that total received through two grants from the National Lottery Heritage Fund, combined with a further 28\% received through crowdfunded contributions from 208 individuals from eight different countries. This funding mix ensured that a range of cost-free opportunities could be provided for dig participants and the wider community alongside crowdfunded experiences. The pop-up museums received 1737 visitors over a 20-day period (peer consumers); this audience was predominantly local, with $46 \%$ of exhibition visitors travelling less than 10 miles and $25 \%$ travelling up to 20 miles. Of the total number of visitors surveyed, $50 \%$ were drawn to the venue because of the exhibition (rather than just passing by) and $40 \%$ represented an entirely new audience as they had never visited an archaeology event before. Education sessions were delivered to 517 primary school students, with special arrangements for group Skype calls to the dig site where archaeologists could reveal their latest finds. A total of 1768 unique visitors accessed the Virtual Museum over the course of a 10-day period during the 2018 season, a social engagement strategy that was supplemented through channels such as Facebook Live where single videos such as the excavation of an urn could garner up to 1838 reactions, comments and shares and 5287 post clicks.

Of the individuals who directly supported the crowdfunding campaign, 48\% were digital contributors (peer consumers), with $13 \%$ of peer-participants joining the team for a week, $17 \%$ for a weekend and $22 \%$ for a day. Of these sub-categories of peer producers, the data base records an average of 1 context and 1.5 finds records for each day participants; 1 context and 2.25 finds records for each weekend participant; and 1.67 contexts, 4 finds records, 1.67 sample records and 1.5 section records for week participants. Set against the baseline data derived from age studies of existing community archaeology groups, this approach can be seen to substantially improve on exiting provision as previously discussed in Figure 2. Each age category was well represented by participants

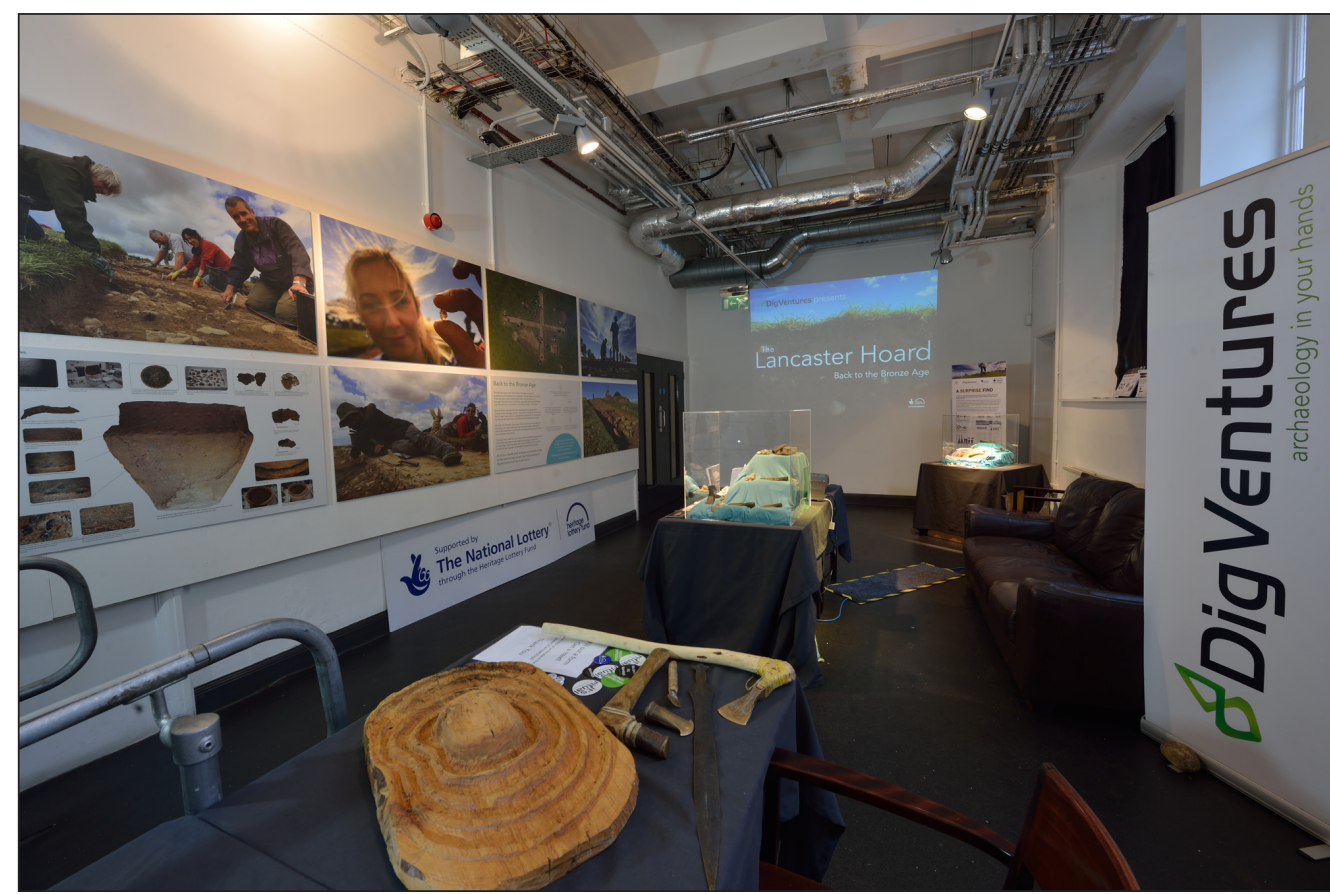

Figure 10: Pop-up Museum in Lancaster city centre, displaying results, artefacts and a live stream to dig for local residents, visitors and school children. DigVentures. 
with a wide representation of socioeconomic profiles (Figure 11), but perhaps more significantly in terms of audience development, $81 \%$ of peer participants had no previous experience of archaeology. A higher proportion of older participants was encountered on this project than other DigVentures excavations (contrast Figure 2, Leiston Abbey). When questioned this group of older peer consumers described being drawn to support the project digitally due to difficulties with physical accessibility but 'still wanting to feel involved', with people aged 74 and older engaged with the project entirely via the digital component of the project. These results are somewhat counterintuitive to the proposition that crowdfunding creates an exclusionary paywall favouring only the wealthy, or that digital engagement creates a barrier in and of itself, particularly amongst older people who are considered to be less digitally literate.

\section{Conclusion - the world is my dig}

This paper has presented a novel theoretical framework and worked project example detailing how a networked peer-to-peer approach to field work can expand civic engagement with archaeological research. Forthcoming doctoral scholarship will introduce a theory of change and evaluative framework for measuring the social impact of public participation (Wilkins 2019: 77), with a longitudinal study of several case studies elucidating the participatory 'scaffolding' necessary for successful outcomes described above (Wilkins in prep). To conclude and return to the subject of this special issue, we should consider how these moves to reposition archaeology as an open and participatory digital platform have been received by practitioners seeking to establish the disciplinary boundaries of what has been defined as 'digital archaeology' (Perry and Taylor 2018: 11) or 'digital public archaeology' (Richardson 2013: 4).

Rather than embracing these experiments with technology-enabled participation and crowd-based digital scholarship, civic participation has largely been seen as potentially exploitive (Fredheim 2017; Perry and Beale 2015), with researchers questioning whether the "introduction of co-production means the economic value of archaeological expertise (and paid archaeological jobs) will survive unscathed" (Richardson and Dixon 2017, 5). Framed as a questionable response to austerity, crowdbased approaches are seen as a method to reduce costs and increase "the potential scope for what can be achieved on a small budget" in "exchange for some form of training and the opportunity to gain what Bourdieu (1986) calls 'social capital"' (Richardson 2017: 6). Perry criticises the "obfuscating discourse" surrounding the cynical acquisition of this social capital, questioning whether "the immediate benefits of crowdsourcing and crowdfunding are eclipsing concern for their profound longer term impacts" (Perry 2015: 384). Sayer questions the "morality" of a crowdfunding model "that actively excludes the wider

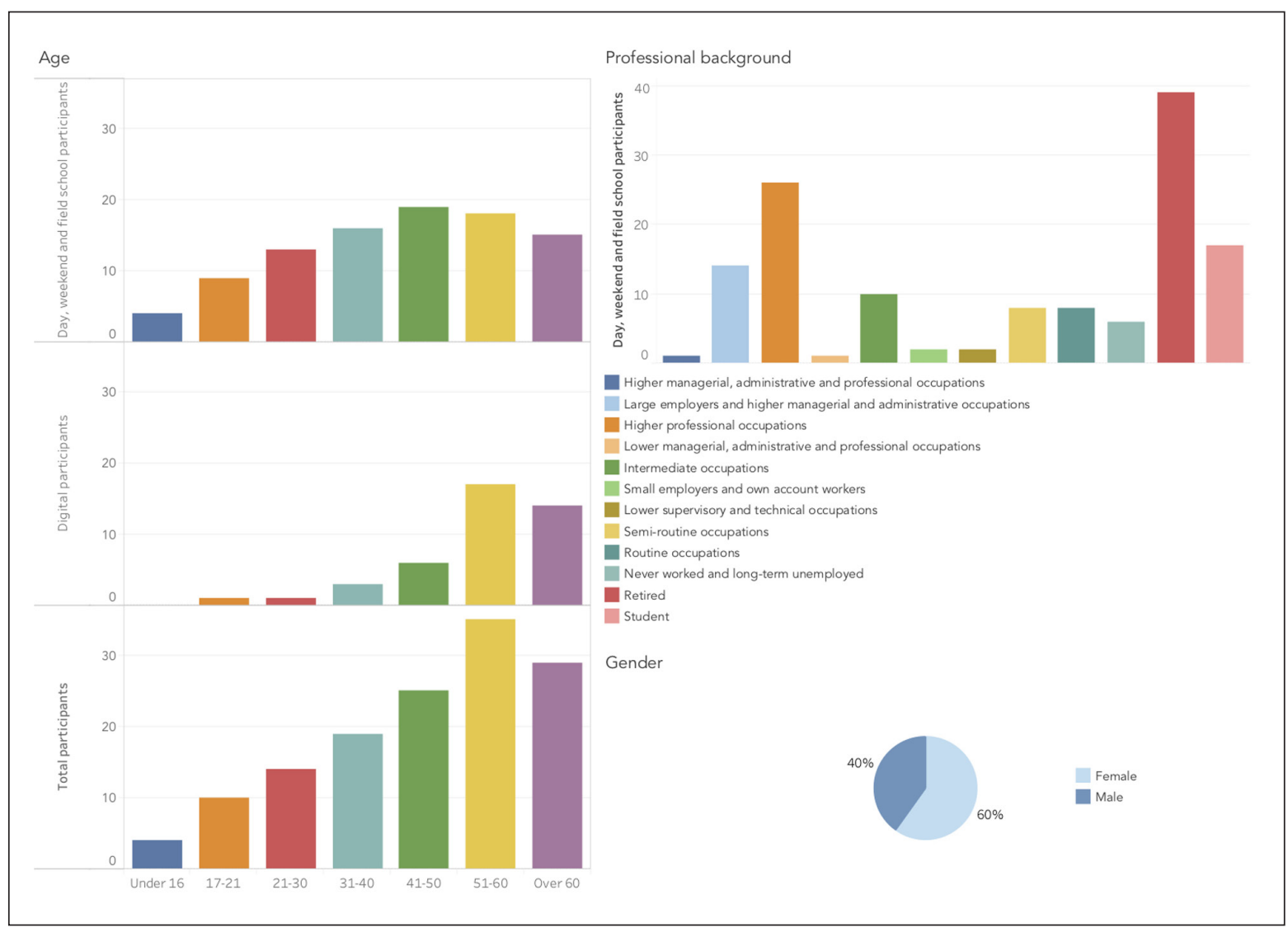

Figure 11: Age, gender and professional background (with categories derived from the Office for National Statistics) of peer producers and consumers who supported the Barrowed Time project, indicating a spike in older, retired participants amongst digital only supporters. DigVentures. 
public through its pricing structure" (Sayer 2014: 67), whilst Richardson asks "are these 'crowds' truly large and representative of the general public, or are they simply a small number of active and keen expert participants..." (Richardson 2014: 209, 2017: 7).

Notwithstanding the justifiable concern with ethics (treated as a design challenge rather than a settled claim in Section 3 above), forcefully argued criticisms of crowdbased archaeology are not well evidenced or theorised. In light of Lifshitz-Assaf's characterisation of problem solvers and solution seekers during similar experiments with crowd-based approaches at NASA discussed above (Lifshitz-Assaf 2017: 757), these strong reactions could be seen as indicative of a perceived challenge to professional identity. Though widely regarded as a success, enthusiasm for open innovation was far from unanimous with NASA's scientific community, leading to "rising tensions, emotions and fragmentation." Problem solvers saw open innovation as running against the grain of their professional raison d'être, with one remarking

"I've been attracted to places that allow you to access a problem, come up with a plan, and execute the solution... to be able to think and solve greater problems. If I can't do it at NASA, what is keeping me from going somewhere else?" $(2017,13)$.

Lifshitz-Assaf noted that successful adoption of an open innovation model would require a "mindset shift," a viewpoint echoed by Timms and Heimans who wryly note that

"this was a group for whom the answer to 'Houston, we've had a problem' could never be 'Stand by, Apollo, we're going to crowdsource that and see if any semi-retired telecommunications engineers in New Hampshire have any insights"' $(2017,18)$.

Although crowd-based digital initiatives have emerged from within archaeology's traditional disciplinary structures, these projects have struggled to build sustaining and scalable digital communities (Bonacchi et al. 2015: 194; Richardson et al. 2018: Section 5), an arguable consequence of not embracing the necessary 'mindset shift' described by Lifshitz-Assaf, or a 'business and operational model-shift' argued for in Section 2 and 3 above. When practitioners face difficulties broadening participation beyond traditional audiences "with higher income and education levels" (Bonacchi et al. 2019: 177), circular reasoning is deployed to argue that low levels of engagement are a natural consequence of the medium, reinforcing Richardson's statement (2014: 282; cited by Richardson et al. 2018: Section 5) that

"we must question whether new landscapes of participatory media can fundamentally change, open, or even threaten the authority of archaeological organisations and academic knowledge."

Designing the DigVentures system with a clean slate approach has transpired to be a huge advantage in this reworking of professional identity, calling forth a solu- tion seeker mind-set that empowers a reimagining of how we fund, resource, record, analyse and communicate our science. A traditional problem solver value system will result in a linear operational model enclosed by disciplinary boundaries, exemplified by Cunliffe's levels of publication, in which the communication of archaeological knowledge with the public maintains the dichotomy of 'us' and 'them'. A solution seeker mind set will enable practitioners to rethink their role in relation to both their subject of study and wider public, underpinned by an open, participatory model that seeks to dismantle disciplinary boundaries. But repositioning the locus of work beyond the physical limits of an organisation does not just enable the public to become citizen scientists. It also engenders the need for archaeologists to become 'scientific citizens', experts who are every bit a part of society as non-experts, with all the responsibilities and rewards that infers.

For legacy organisations and projects seeking to successfully embrace crowd-based digitally networked tools, the first challenge is to undertake what Lifshitz-Assaf calls "a shift in one's professional role and one's identity when challenged by a new technology... changing the focus of 'How' we do our work, to pause, reflect and refocus on the bigger 'Why'” (Lifshitz-Assaf 2018). As one of the subjects in Lifshitz-Assaf's study described, it is a transformation from thinking "The lab is my world" to "The world is my lab" - a sentiment to which we can now add the word: dig.

\section{Acknowledgements}

This paper was kindly supported by a scholarship from the College of Social Sciences, Arts and Humanities at the University of Leicester. The open access publication of this article is supported by COST (European Cooperation in Science and Technology) and the COST Action ARKWORK. Sincere thanks to all the staff at the School of Museum Studies, and particularly to Giasemi Vavoula, Matthew Allen (School of Business) and Oliver Harris (Department of Archaeology and Ancient History) for comments and continued help and guidance. Final thanks to the team at DigVentures for companionship on the journey, and the overwhelming support of our peer community, without whom this work would not exist.

This article is based upon work from COST Action ARKWORK, supported by COST (European Cooperation in Science and Technology). www.cost.eu.

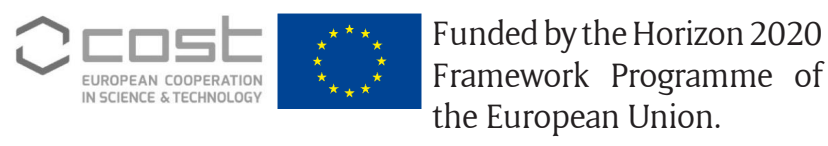

\section{Competing Interests}

The author has no competing interests to declare.

\section{References}

Aitcheson, K. 2019. State of the Archaeology Market 2018. Landward Research. Available at: https:// www.archaeologists.net/sites/default/files/Archaeological\%20Market\%20Survey\%202017-18.pdf [Last accessed: 10 November 2019].

Bell, D. 1973. The Coming of Post-industrial Society: A Venture in Social Forecasting. London: Penguin. 
Benkler, Y. 2004. 'Sharing Nicely': On Sharable Goods and the Emergence of Sharing as a Modality of Economic Production. Yale Law Journal, 114(2): 273-358. DOI: https://doi.org/10.2307/4135731

Benkler, Y. 2006. The Wealth of Networks: How Social Production Transforms Market and Freedom. New Haven and London: Yale University Press.

Benner, M and Tushman, ML. 2015. Reflections on the 2013 decade award: 'Exploitation, exploration, and process management: The productivity dilemma' revisited ten years later. Academy of Management Journal, 40: 497-514. DOI: https://doi. org/10.5465/amr.2015.0042

Berggren, A, Dell'Unto, N, Forte, M, Haddow, S, Hodder, I, Issavi, J, Lercari, N, Mazzucato, C, Mickel, A and Taylor, JS. 2015. Revisiting reflexive archaeology at Çatalhöyük: integrating digital and 3D technologies at the trowelis edge. Antiquity, 89: 433-448. DOI: https://doi.org/10.15184/ aqy. 2014.43

Berggren, A and Hodder, I. 2003. Social practice, method, and some problems of field archaeology. American Antiquity, 68(3): 421-434. DOI: https:// doi.org/10.2307/3557102

Bonacchi, C, Pett, D, Bevan, A and Keinan-Schoonbaert, A. 2015. Experiments in Crowd-funding Community Archaeology. Journal of Community Archaeology \& Heritage, 2(3): 184-198. DOI: https://doi.org/10.11 79/2051819615Z.00000000041

Botsman, R and Rogers, R. 2011. What's Mine is Yours: The Rise of Collaborative Consumption. New York: Harper Collins.

Bourdieu, P. 1986. Distinction: A Social Critique of the Judgement of Taste. New York: Routledge.

Boyd, C. 2018. Post-Capitalist Entrepreneurship: Startups for the 99\%. Boca Ranton: CRC Press.

Bradley, R. 2006. Bridging the two cultures: Commercial archaeology and the study of prehistoric Britain. Antiquaries Journal, 86: 1-13. DOI: https://doi. org/10.1017/S0003581500000032

Braverman, H. 1974. Labour and Monopoly Capital: The Degradation of Work in the Twentieth Century. New York: Monthly Review Press.

Brophy, K. 2018. The Brexit hypothesis and prehistory. Antiquity, 92(366): 1650-1658. DOI: https://doi. org/10.15184/aqy.2018.160

Caraher, W. 2016. Slow Archaeology: Technology, Efficiency, and Archaeological Work. In: Walcek Averett, D, et al. (eds.), Mobilizing the Past: Recent Approaches to Archaeological Fieldwork in a Digital Age, 421-442. Grand Forks: The Digital Press at the University of North Dakota.

Carver, M. 2010. Editorial. Antiquity, 84: 935-938. DOI: https://doi.org/10.1017/S0003598X00066990

Carver, M. 2011. Making Archaeology Happen: Design versus Dogma. New York and London: Routledge.

Chevalier, JM and Buckles, DJ. 2013. Participatory Action Research: Theory and Methods for Engaged Inquiry. London and New York: Routledge.
Chesbrough, H. 2003. Open Innovation: The New Imperative for Creating and Profiting from Technology. Boston: Harvard Business School Press.

Chesbrough, H, Vanhaverbeke, HW and West, J. 2014 New Frontiers in Open Innovation. Oxford: Oxford University Press. DOI: https://doi.org/10.1093/acp rof:oso/9780199682461.001.0001

Cicero, S. 2018. Platform Design Toolkit: the user guide v2.1. Boundaryless SRL. Available at: https://platformdesigntoolkit.com/toolkit/ [Last accessed 10 Nov 2019].

Clarke, A, Fulford, M and Rains, M. 2003. Nothing to hide - online database publication and the Silchester Town Life Project. In: Doerr, M and Sarris, A (eds.), CAA 2002. The Digital Heritage of Archaeology. Computer Applications and Quantitative Methods in Archaeology, Proceedings of the 30th Conference, Heraklion, Crete, April 2002, 401-404. Greece: Hellenic Ministry of Culture.

Costopoulos, A. 2016. Digital archaeology is here (and has been for a while). Frontiers in Digital Humanities, 3(4): 1-3. DOI: https://doi.org/10.3389/ fdigh.2016.00004

Cunliffe, BW. 1983. The Publication of Archaeological Excavations: Report of a Joint Working Party of the Council for British Archaeology and the Department of the Environment. London: Department of the Environment.

Dore, C. 2019. Value, Sustainability and Heritage Impact. The Archaeologist, 108: 24-26. Available at https:// www.archaeologists.net/publications/archaeologist [Last accessed: 10 November 2019].

Everill, P. 2009. The Invisible Diggers. A study of British Commercial Archaeology. Oxford: Oxbow.

Fairbnb. 2019. Manifesto. Available at: https://fairbnb. coop/\#manifesto [Last accessed: 10 November 2019].

Frearson, D. 2018. Supporting Community Archaeology in the UK: Results of a 2018 Survey. CBA Research Bulletin 6. York: Council for British Archaeology.

Fredheim, LH. 2017. Endangerment-driven Heritage Volunteering: Democratisation or 'Changeless Change'. International Journal of Heritage Studies, 24(6): 619-633. DOI: https://doi.org/10.1080/135 27258.2017.1399285

Fulford, M. 2011. The impact of commercial archaeology on the UK heritage. In: Curtis, J, Fulford, M, Harding, A and Reynolds, F (eds.), History for the taking? Perspectives on material heritage, 33-53. London, UK: British Academy.

Fulford, M and Holbrook, N. (eds.). 2015. The towns of Roman Britain: the contribution of commercial archaeology since 1990 (Britannia Monograph 27). London: The Society for the Promotion of Roman Studies.

Galeazzi, F and Richardson-Rissetto, H. 2018. Editorial Introduction: Web-based Archaeology and Collaborative Research. Journal of Field Archaeology, 43(sup 1): S1-S8. DOI: https://doi.org/10.1080/00934690 .2018 .1512701 
Gibson, W. 1990. Cyberpunk (Documentary), Directed by Marianne Trench, Produced by Peter von Brandenburg, An Intercon Production. Timecode, 12:20 of 14:59. Available at https://youtu.be/ xxTuEGEl9EQ?t=740 [Last accessed 10 November 2019].

González-Ruibal, A. 2018. Beyond the Anthropocene: Defining the Age of Destruction. Norwegian Archaeological Review, 51(1-2): 10-21. DOI: https://doi. org/10.1080/00293652.2018.1544169

González-Ruibal, A, González, P and Criado-Boado, F. 2018. Against reactionary populism: Towards a new public archaeology. Antiquity, 92(362): 507-515. DOI: https://doi.org/10.15184/aqy.2017.227

Graber, D. 2015. The Utopia of Rules: On Technology, Stupidity, and the Secret Joys of Bureaucracy. London: Melville House.

Graber, D. 2018. Bullshit Jobs: A Theory. London: Allen Lane

Hedge, R and Nash, A. 2016. Assessing the Value of Community-Generated Historic Environment Research. Historic England and Worcestershire County Council. Available at https://research.historicengland. org.uk/Report.aspx?i=15842 [Last accessed 10 November 2019].

Huvila, I and Huggett, J. 2018. Archaeological Practices, Knowledge Work and Digitalisation. Journal of Computer Applications in Archaeology, 1(1): 88-100. DOI: https://doi.org/10.5334/jcaa.6

Jones, B. 1984. Past Imperfect: The Story of Rescue Archaeology. London: Blackwell.

Kristiansen, K. 2009. Contract archaeology in Europe: an experiment in diversity. World Archaeology, 41(4): 641-648. DOI: https://doi. org/10.1080/00438240903371486

Lancaster City Council. 2019. About the Local Plan. Available at: http://www.lancaster.gov.uk/planning/planning-policy/about-the-local-plan [Last accessed: 10 November 2019].

Lifshitz-Assaf, H. 2017. Dismantling Knowledge Boundaries at NASA: The Critical Role of Professional Identity in Open Innovation. Administrative Science Quarterly, 63(4): 746-782. DOI: https://doi. org/10.1177/0001839217747876

Lifshitz-Assaf, H. 2018. NYU Stern Professor Hila Lifshitz-Assaf on Innovation at NASA. 21 ${ }^{\text {st }}$ May 2018 [online access at https://youtu.be/Lzw8kS1YJgM last accessed 10 November 2019].

Lukas, D, Engel, C and Mazzucato, C. 2018. Towards a Living Archive: Making Multi Layered Research Data and Knowledge Generation Transparent. Journal of Field Archaeology, 43(sup1): S19-S30. DOI: https:// doi.org/10.1080/00934690.2018.1516110

Manley, J. 1999. Old stones, new fires: The local societies. In: Beavis, J and Hunt, A (eds.), Communicating Archaeology, 105-12. Oxford: Oxbow. DOI: https:// doi.org/10.2307/j.ctvh1dhfr.18

Mason, P. 2019. The new spirit of postcapitalism. International Politics and Society. Available at: https:// www.ips-journal.eu/regions/europe/article/ show/the-new-spirit-of-postcapitalism-3381/ [Last accessed: 10 November 2019].

Matsuda, A. 2016. A Consideration of Public Archaeology Theories, Public Archaeology, 15(1): 40-49. DOI: https://doi.org/10.1080/14655187.2016.1209377

McAnany, PA and Rowe, SM. 2015. Re-visiting the field: Collaborative archaeology as paradigm shift. Journal of Field Archaeology, 40(5): 499-507. DOI: https://doi.org/10.1179/2042458215Y.000000 0007

Morgan, C and Eve, S. 2012. DIY and digital archaeology: what are you doing to participate? World Archaeology, 44(4): 521-537. DOI: https://doi.org/ 10.1080/00438243.2012.741810

Nativ, A. 2018. On the object of archaeology. Archaeological Dialogues, 25(1): 1-21. DOI: https://doi. org/10.1017/S1380203818000016

Neal, C. 2015. Heritage and Participation. In: Waterton, E and Watson, S (eds.), The Palgrave Handbook of Contemporary Heritage Research, 346-365. UK: Palgrave Macmillan. DOI: https://doi. org/10.1057/9781137293565_22

Nixon, T. 2017. What about Southport? A report to CIfA on progress against the vision and recommendations of the Southport Report (2011), undertaken as part of the 21st-century challenges in archaeology. Available at: http://www.archaeologists.net/21stcentury-challenges-archaeology [Last accessed: 10 November 2019].

Olivier, ACH. 1987. Excavation of a Bronze Age Funerary Cairn at Manor Farm, near Borwick, North Lancashire. Proceedings of the Prehistoric Society, 53: 129-186. DOI: https://doi.org/10.1017/ S0079497X00006186

Oxford Dictionary. 2016. Word of the Year 2016 is... Available at: https://en.oxforddictionaries.com/ word-of-the-year/word-of-the-year-2016 [last accessed 10 November 2019].

Pariser, E. 2011. The Filter Bubble: What the Internet is Hiding From You. New York: Penguin. DOI: https:// doi.org/10.3139/9783446431164

Perry, S. 2015. Who actually profits from web-based crowdsourcing and crowdfunding in Archaeology? A Critique of the short and long-term impacts of crowd work. Paper presented to the EAA, Glasgow, 384. Abstracts Book.

Perry, S. 2019. The Enchantment of the Archaeological Record. European Journal of Archaeology, 22: 354-371. DOI: https://doi.org/10.1017/ eaa.2019.24

Perry, S and Beale, N. 2015. The Social Web and Archaeology's Restructuring: Impact, Exploitation, Disciplinary Change. Open Archaeology, 1: 153-165. DOI: https://doi.org/10.1515/opar-2015-0009

Perry, S and Taylor, JS. 2018. Theorising the Digital: A Call to Action for the Archaeological Community. In: Matsumoto, M, et al. (eds.), Oceans of Data: Proceedings of the 44th Conference on Computer Applications and Quantitative Methods in Archaeology, 11-22. Oxford: Archaeopress. 
Pick, F. 2019. Welcome to the age of participation. In: Cabraal, A and Basterfield, S (eds.), Better work together: how the power of community can transform your business. Weelington: Enspiral Foundation.

Poehler, EE and Ellis, SJR. 2012. The 2011 Season of the Pompeii Quadriporticus Project: The Southern and Northern Sides. Fasti Online Documents and Research, 249: 1-12. Available at https://core. ac.uk/download/pdf/33151446.pdf [Last accessed 10 November 2019].

Powlesland, D and May, K. 2010. DigIT: Archaeological Summary Report and Experiments in Digital Recording in the Field. Internet Archaeology, 27. DOI: https://doi.org/10.11141/ia.27.2

Richardson, L-J. 2013. A Digital Public Archaeology? Papers from the Institute of Archaeology, 23(1): 1-12. DOI: https://doi.org/10.5334/pia.431

Richardson, L-J. 2014. Public Archaeology in a Digital Age, Unpublished thesis (PhD) thesis, University College London, London, UK. Available at: http:// figshare.com/authors/Lorna_Richardson/606491 [Last accessed: 13th April 2019].

Richardson, L-J. 2017. I'll give you 'punk archaeology', sunshine. World Archaeology, 49(3): 306-317. DOI: https://doi.org/10.1080/00438243.2017.1333036

Richardson, L-J and Dixon, J. 2017. Public Archaeology 2015: Letting public engagement with archaeology 'speak for itself'. Internet Archaeology, 46. DOI: https://doi.org/10.11141/ia.46.7

Richardson, L-J, Law, M, Andrew Dufton, J, Ellenberger, K, Eve, S, Goskar, T, Ogden, J, Pett, D and Reinhard, A. 2018. Day of Archaeology 2011-2017: Global Community, Public Engagement, and Digital Practice. Internet Archaeology, 47. DOI: https://doi.org/10.11141/ia.47.10

Roosevelt, CH, Cobb, P, Moss, E, Olson, BR and Ünlüsoy, S. 2015. Excavation is Destruction Digitization: Advances in Archaeological Practice. Journal of Field Archaeology, 40(3): 325-346. DOI: https://doi.org/ 10.1179/2042458215Y.0000000004

Rosenberg, S. 1992. Virtual Reality Check Digital Daydreams, Cyberspace Nightmares. San Francisco Examiner, Section: Style, 19 April, C1.

Sayer, F. 2014. Politics and the Development of Community Archaeology in the UK, The Historic Environment: Policy \& Practice, 5(1): 55-73. DOI: https:// doi.org/10.1179/1756750513Z.00000000041

Scanlon, K, Fernandez, M, Travers, T and Whitehead, C. 2011. An economic analysis of the market for archaeological services in the planning process. In: The Southport Group (eds.), Realising the benefits of planning-led investigation in the historic environment: a framework for delivery. Reading: Institute for Archaeologists. Available at: https://www.archaeologists.net/sites/default/files/SouthportreportA4. pdf [Last accessed: 10 November 2019].

Shanks, M and Witmore, C. 2012. Archaeology 2.0? Review of Archaeology 2.0: New Approaches to Communication and Collaboration [Web Book]. Internet Archaeology, 32. DOI: https://doi.org/10.11141/ia.32.7
Shapiro, C and Varian, HR. 1999. Information Rules: A Strategic Guide to the Network Economy. Harvard: Harvard Business Review.

Stokes, K, Clarence, E, Anderson, A and Rinne, A. 2014 Making sense of the UK Collaborative Economy. Nesta. Available at: https://media.nesta.org.uk/ documents/making_sense_of_the_uk_collaborative_economy_14.pdf [Last accessed: 10 November 2019].

Taylor, JS, Issavi, J, Berggren, A, Lukas, D, Mazzucato , C, Tung, B and Dell'Unto, N. 2018. 'The Rise of the Machine': the impact of digital tablet recording in the field at Çatalhöyük. Internet Archaeology, 47. DOI: https://doi.org/10.11141/ia.47.1

Thomas, S. 2010. Community Archaeology in the UK: Recent Findings. York: Council for British Archaeology.

Timms, H and Heimans, J. 2018. New Power: How it's changing the $21^{\text {st }}$ century - and why you need to know. London: Macmillan

Trigger, B. 2006. A History of Archaeological Thought, $2^{\text {nd }}$ Edition. Cambridge: Cambridge University Press.

Trow, S. 2016. 25 Years of Development-led Archaeology in England: Strengths, Weaknesses, Opportunities and Threats. In: Novaković, P, Horňák, M, Guermandi, M, Stäuble, H, Depaepe, P and Demoule, J-P. (eds.), Recent Developments in Preventive Archaeology in Europe. Proceedings of the 22nd EAA Meeting in Vilnius, 2016. Ljubljana: Ljubljana University Press. Available at: https://pdfs.semanticscholar.org/dc2d/7b31d895ec69bd6054cbe1b 7ce94965e05bd.pdf [Last accessed 10 November 2019].

Von Hippel, E. 1988. Sources of Innovation. Oxford: Oxford University Press.

Von Hippel, E. 2005. Democratizing Innovation. Cambridge, MA: MIT Press. DOI: https://doi. org/10.7551/mitpress/2333.001.0001

Wainwright, G. 2000. Time Please. Antiquity, 74(286): 909-943. DOI: https://doi.org/10.1017/ S0003598X00060555

Walcek Averett, A, Gordon, JM and Counts, DB. (eds.) 2016. Mobilizing the Past for a Digital Future. Grand Forks: The Digital Press at The University of North Dakota.

Watson, S. 2019. Whither archaeologists? Continuing challenges to field practice. Antiquity, 1-10. DOI: https://doi.org/10.15184/aqy.2019.141

Westcott Wilkins, L. 2015. The 'Real-Time' Team: The future of fieldwork. Current Archaeology, 302: $36-40$.

Wilkins, B. 2009. Rumsfeldian Archaeology. Current Archaeology, 231: 43. Available at https://www. archaeology.co.uk/issues/ca-231.htm [Last accessed 10 November 2019].

Wilkins, B. 2012. Social Contract Archaeology: a business case for the future. Paper presented to the 18th annual meeting of the EAA, Helsinki, Finland.

Wilkins, B. 2013. DigVentures. The Archaeologist, 90: 46-47. Available at https://www.archaeologists. 
net/sites/default/files/TA90-Website.pdf [Last accessed 10 November 2019].

Wilkins, B. 2019. A theory of change and evaluative framework for measuring the social impact of public participation in archaeology. European Journal of Postclassical Archaeologies, 9: 77-100

Wilkins, B. In Prep. Digging the Crowd: the future for archaeology in the digital and collaborative economy. PhD Thesis. University of Leicester, School of Museum Studies.

Wilkins, B, Noon, S, Roberts, B, Ungemach, J and Caswell, E. 2018. Barrowed Time: A CommunityBased Archaeological Excavation, Lancashire. DigVentures. Available at: https://digventures.com/ reports/?fwp_reports_project=barrowed-time [Last Accessed 10 November 2019].

Willems, W and van den Dries, M. 2007. The origins and development of quality assurance in archaeology.
In: Willems, W and van den Dries, M (eds.), Quality Management in Archaeology, 1-12. Oxford: Oxbow Books.

Wills, J. 2018. The world after PPG16: 21st century challenges for archaeology. Reading: Historic England \& CIfA.

Woolverton, J. 2016. 'Becoming History Ourselves': A Study of Age Demographics in Community Archaeology Societies. Journal of Community Archaeology \& Heritage, 3(2): 135-151. DOI: https://doi.org/10.10 80/20518196.2016.1154741

Wylie, A. 2014. Community-Based Collaborative Archaeology. In: Cartwright, $\mathrm{N}$ and Montuschi, E (eds.), Philosophy of Social Science: a new Introduction, 68-82. Oxford: Oxford University Press.

Zuboff, S. 2019. The Age of Surveillance Capitalism: The Fight for a Human Future at the New Frontier of Power. London: Profile Books.

How to cite this article: Wilkins, B. 2020. Designing a Collaborative Peer-to-peer System for Archaeology: The DigVentures Platform. Journal of Computer Applications in Archaeology, 3(1), pp. 33-50. DOI: https://doi.org/10.5334/jcaa.34

Submitted: 22 January 2019 Accepted: 11 February $2020 \quad$ Published: 23 March 2020

Copyright: (c) 2020 The Author(s). This is an open-access article distributed under the terms of the Creative Commons Attribution 4.0 International License (CC-BY 4.0), which permits unrestricted use, distribution, and reproduction in any medium, provided the original author and source are credited. See http://creativecommons.org/licenses/by/4.0/.

$\mathrm{u}$ [ Journal of Computer Applications in Archaeology, is a peer-reviewed open access journal published by Ubiquity Press. 